УДК 619:636.09:616.98:636.5

(C) 2013

Обуховська О. В., Руденко О. П., кандидати ветеринарних наук, Матюша Л. В., молодший науковий співробітник, Попова О. М., ветеринарний лікар

Національний науковий центр «Інститут експериментальної і клінічної ветеринарної медицини»

\title{
БІЛКОВІ ФРАКЦІЇ СИРОВАТКИ КРОВІ У КУРЕЙ, ЩЕПЛЕНИХ ІНАКТИВОВАНИМИ ВАКЦИНАМИ ПРОТИ РЕСПІРАТОРНОГО МІКОПЛАЗМОЗУ ПТИЦІ
}

\section{Рецензент - кандидат ветеринарних наук К. В. Глєбова}

Доведено, щз дворазове внутрішньом'язеве введення інактивованих вакцин проти респіраторного мікоплазмозу птищі сприяе підвищенню рівня альбумінів $i$ ү-глобулінів у сироватиі крові курей, щуо свідчить про активізацію імунної системи організму. Застосування вакцини на основі інактивованого бактерину підвищує рівень альбумінів на 47,0\% та ү-глобулінів на 91,9\% на 21-иу добу після другого введення препарату. Застосування за аналогічною схемою субодиничної вакцини на основі дезінтегрованої бакмаси підвищує рівень альбумінів на 39,6\% та ү-глобулінів на 84,2\% відповідно.

Ключові слова: респіраторний мікоплазмоз птииі, інактивовані вакцини, альбуміни, ү-глобуліни.

Постановка проблеми. Розробка вітчизняних вакцинних препаратів для профілактики респіраторного мікоплазмозу птиці - актуальний напрям наукової роботи. Одним із найважливіших показників дії вакцин на організм птиці є зміна рівня білкових фракцій крові в певні періоди після імунізації. Достовірне збільшення рівня альбумінів і $\gamma$-глобулінів свідчить про активізацію імунної системи й підтверджує ефективність вакцинного препарату. Тому визначення цих показників, поряд із рівнем захисних антитіл та визначенням проективного захисту в процесі прямого зараження імунізованої птиці, вважають необхідним етапом вивчення дії нових вакцин $[1,2]$.

Аналіз основних досліджень і публікацій, у яких започатковано розв'язання проблеми. Ефективність і доцільність застосування вакцинації для профілактики респіраторного мікоплазмозу птиці не підлягає сумніву [5-7, 9]. Доведено, що економічні витрати на вакцинацію $\epsilon$ незначними у порівнянні зі збитками, що їх спричиняє спалах захворювання [8]. Інактивовані вакцини широко застосовуються та вважаються більш безпечними й ефективними, ніж живі [4, 10-12]. Нами було виготовлено дві серії інактивованих вакцин проти респіраторного мікоплазмозу птиці та проведені досліди щодо вивчення ефективності їх застосування в дослідах на курях. Доведено, що вони забезпечують захист
100 \% птиці від клінічних проявів захворювання та $95 \%$ птиці - від зараження штамом-пробійником [3].

Мета і завдання. Метою роботи було визначення характеру впливу двох інактивованих вакцин проти респіраторного мікоплазмозу на організм птиці та порівняльний аналіз ефективності ïх застосування.

Для досягнення цієї мети було визначено завдання: вивчити динаміку зміни рівня альбумінів та $\gamma$-глобулінів у сироватці крові курей після дворазового внутрішньом'язевого введення вакцин у порівнянні 3 аналогічними показниками у невакцинованої птиці.

Матеріали і методи. Експериментальні серії інактивованих вакцин проти респіраторного мікоплазмозу птиці були виготовлені за двома різними методиками. У першій серії в якості антигенної основи застосовували інактивований бактерин виробничого штаму Mycoplasma gallisepticum S6 (ВБ). У другій серії в якості антигенної основи застосовували дезінтегровану бактерійну масу клітин виробничого штаму Mycoplasma gallisepticum S6 (BC). До стандартизованих інактивованих антигенних основ додавали ад'ювант із розрахунку: $30 \%$ антигенної основи $\left(3 \times 10^{7}\right.$ КУО) та $70 \%$ ад'юванту (Mantanide ISA 70 VG). Виготовлені вакцини перевіряли на стерильність (за ДСТУ 4483) і нешкідливість (за ДСТУ 46.024). Досліди були проведені на 3-х групах курей. Перша дослідна група $(\mathrm{n}=30)$ була імунізована внутрішньом'язево дворазово (в віці 30 та 60 діб) інактивованою вакциною проти респіраторного мікоплазмозу птиці на основі бактерину (ВБ). Другу дослідну групу $(\mathrm{n}=30)$ імунізували внутрішньом'язево дворазово (в віці 30 та 60 діб) інактивованою субодиничною вакциною на основі дезінтегрованої бакмаси штаму Mycoplasma gallisepticum S6 (BC).

Контрольна група $(\mathrm{n}=30)$ імунізації не піддавалась.

Від птиці всіх груп відбирали проби крові за 


\section{ВЕТЕРИНАРНА МЕДИЦИНА}

добу до вакцинаціі, а також на 7-му і 14-ту добу після першого введення вакцин та на 7-му, 14-ту і 21-шу добу після другого введення.

В сироватці крові визначали рівень альбумінів за реакцією 3 бромкрезоловим зеленим та $\gamma$-глобулінів турбодиметричним методом.

Усі результати обраховували статистично (програма SPASS Statistics 17.0).
Результати досліджень. Аналіз результатів вивчення зміни значень білкових фракцій крові в сироватці крові курей дослідних груп показав, що введення обох вакцинних препаратів сприяло значному підвищенню рівня альбумінів i $\gamma$-глобулінів. Слід зауважити, що значення цих показників і терміни виявлених змін були дещо різними для обох дослідних груп. Ці зміни відображено на рис. 1, 2.

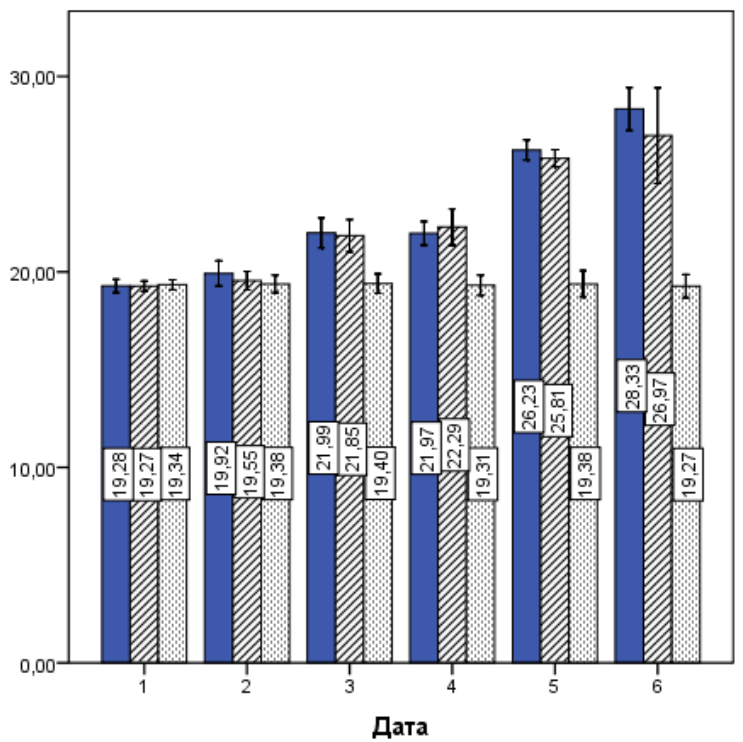

吕B Контроль

1 - до введення вакцин; 2 - 7-ма доба після першого введення; 3-14-та доба після першого введення; 4 - 7-ма доба після другого введення; 5-14-та доба після другого введення; 6-21-ша доба після другого введення

Рис. 1. Динаміка зміни рівня альбумінів у сироватці крові курей дослідних і контрольної груп

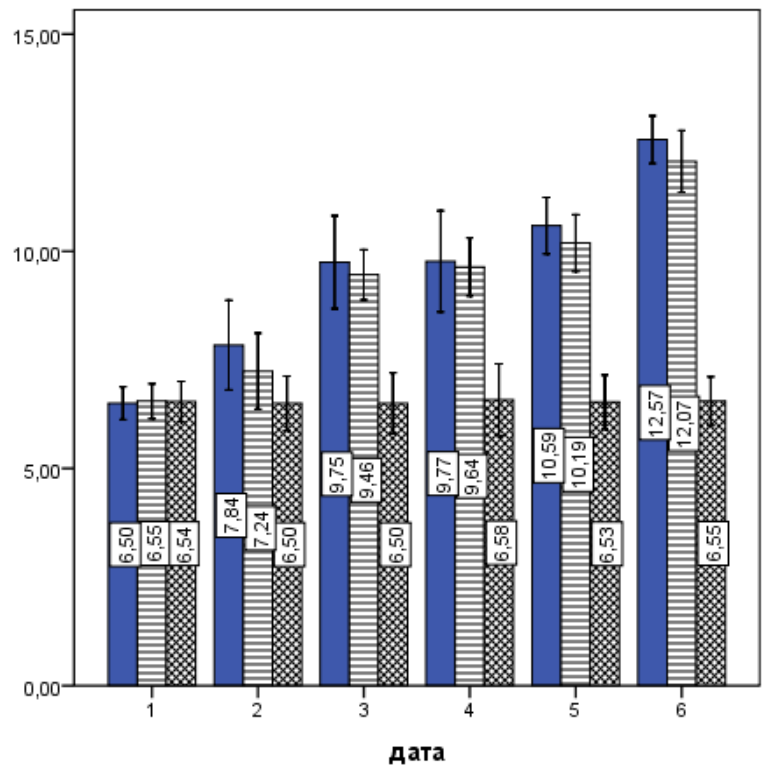

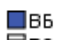
自 Контроль

1 - до введення вакцин; 2 - 7-ма доба після першого введення; 3 - 14-та доба після першого введення; 4 - 7-ма доба після другого введення; 5 - 14-та доба після другого введення; 6-21-ша доба після другого введення

Рис. 2. Динаміка зміни рівня у-глобулінів у сироватці крові курей дослідних та контрольної груп 


\section{ВЕТЕРИНАРНА МЕДИЦИНА}

Як видно $з$ даних рис. 1, рівень альбумінів у сироватці крові курей обох дослідних груп поступово зростав, починаючи 3 7-ої доби після першого введення вакцин. Так, у групі ВБ ми виявляли підвищення цього показника на 14 \% у порівнянні $з$ контролем на 14-ту добу після першого введення. На 7-му добу після другого введення він практично залишався на такому ж рівні $(21,97$ г/л), але потім поступово зростав і сягав свого максимального значення $(28,33$ г/л) на 21шу добу після другого введення препарату, що на $47 \%$ перевищувало показник контрольної групи.

У групі ВС спостерігали схожі зміни: рівень альбумінів зростав після першого введення вакцини (21,85 г/л на 14-ту добу); потім реєстрували незначне підвищення його - до 22,29 г/л на 7-у добу після другого введення. Надалі виявляли підвищення практично на $33 \%$ у порівнянні 3 контролем, максимальний рівень альбумінів у цій групі становив 26,97 г/л (21-а доба), що на 39,6 \% вище, ніж у контрольній групі, але на 5 \% нижче, ніж у групі ВБ.

3 усіх глобулінових фракцій сироватки крові у курей найбільш важливими для оцінки інтенсивності імунної відповіді $є ~ \gamma$-глобуліни, бо у птиці саме до цієї фракції входять IgG, IgA та IgM. У сироватці крові курчат дослідних груп було відмічено збільшення рівня цих білків після першого та другого введень вакцин (рис. 2).

У групі ВБ після першого введення вакцини на 7-му та 14-ту добу їх виявляли в кількості 7,84 г/л та 9,75 г/л, що на 20,6 \% та 50,0 \% вище,

\section{БІБЛІОГРАФІЯ}

1. Белковый спектр крови цыплят-бройлеров при добавлении в рацион лизина сульфата / С. Д. Чернявских, Ж. А. Боролаева, Н. А. Мусиенко, И. Н. Яковлева // Научн. Ведомости Белгородск. госуд. ун-та. Серия: Естественные науки. - 2012. - Т. 19; № 9. - С. 156-158.

2. Болотников И. А. Практическая иммунология сельскохозяйственной птицы / И. А. Болотников, Ю. В. Конопатов. - СПб. : Наука, 1993. $204 \mathrm{c}$.

3. Обуховська О. В. Визначення рівня протективного захисту інактивованої вакцини проти респіраторного мікоплазмозу птиці в досліді на курчатах / О. В. Обуховська // Вісник Полтавської державної аграрної академії. - Полтава, 2013. - № 1. - C. 103-106.

4. Crespo R. Facial cellulitis induced in chickens by Mycoplasma gallisepticum bacterin and its treatment / R. Crespo, R. McMillan // Avian Dis. 2008. - 52(4). - P. 698-701. ніж у контролі, а після другого введення - в кількостях 9,77 г/л на 7-му добу та 12,57 г/л - на 21-шу добу, що практично вдвічі перевищувало аналогічний показник у контрольній групі.

У групі ВС збільшення рівня цієї фракції білків було менш інтенсивним: на 7-му та 14-ту добу після першого введення - 7,24 г/л та 9,46 г/л; після другого введення від 9,64 г/л на 7-му добу до 12,07 г/л - на 21-шу добу, що в незначній мірі (на 4 \%) було нижче, ніж у групі ВБ.

Максимальні значення $\gamma$-глобулінів у сироватці крові курей дослідних груп перевищували аналог для контрольної групи на 91,9 \% (ВБ) та 84,3 \% (ВС) відповідно.

\section{Висновки:}

1. Дворазове внутрішньом'язеве введення інактивованих вакцин проти респіраторного мікоплазмозу птиці сприяє підвищенню рівня альбумінів та $\gamma$-глобулінів у сироватці крові курей, що свідчить про активізацію імунної системи організму. Однак, за результатами аналізу біохімічних показників сироватки крові курей більш доцільним є застосування вакцини на основі інактивованого бактерину.

2. Застосування вакцини на основі інактивованого бактерину (ВБ) підвищує рівень альбумінів на 47,0 \% і $\gamma$-глобулінів на 91,9 \% на 21-шу добу після другого введення препарату.

3. Застосування вакцини за тією ж схемою субодиничної вакцини на основі дезінтегрованої бакмаси (BC) підвищує рівень альбумінів на $39,6 \%$ та $\gamma$-глобулінів на 84,2 \% на 21-шу добу після другого введення препарату.

5. Development and immunogenicity of recombinant $\operatorname{GapA}(+)$ Mycoplasma gallisepticum vaccine strain ts-11 expressing infectious bronchitis virus-S1 glycoprotein and chicken interleukin-6 / P. K. Shil, A. Kanci, G. F. Browning, P. F. Markham // Vaccine. - 2011. - 29(17). - P. 3197-3205.

6. Development and immunogenicity of recombinant Mycoplasma gallisepticum vaccine strain ts-11 expressing chicken IFN-gamma / Y. Muneta [et al.] // Vaccine. - 2008. - 26(43). - P. 5449-5454.

7. Effects of an S6 strain of Mycoplasma gallisepticum challenge before beginning of lay on various egg characteristics in commercial layers / T. A. Parker [et al.] // Avian Dis. - 2002. - Vol. 46, № 3. - P. 593-597.

8. Halvorson D. A. Biosecurity on a multiple-age egg production complex: a 15-year experience / D. A. Halvorson // Avian Dis. - 2011. - 55(1). P. 139-142.

9. Kleven $S$. H. Control of avian mycoplasma in- 


\section{ВЕТЕРИНАРНА МЕДИЦИНА}

fections in commercial poultry / S. H. Kleven // Avian Dis. - 2008. - 52(3). - P. 367-374.

10. Olanrewaju H. A. Effects of single and combined Mycoplasma gallisepticum vaccinations on blood electrolytes and acid-base balance in commercial egg-laying hens / H. A. Olanrewaju, S. D. Collier, S. L. Branton // Poult. Sci. - 2011. 90(2). - P. 358-363.
11. Protective immune response of Mycoplasma gallisepticum vaccines in poultry / Ael-D. Hussein [et al.] // Egypt J. Immunol. - 2007. - 14(2). P. 93-99.

12. The efficacy of three commercial Mycoplasma gallisepticum vaccines in laying hens / N. FergusonNoel, K. Cookson, V. A. Labinis, S. H. Kleven // Avian Dis. - 2012. - 56(2). - P. 272-275. 